\title{
THE PROFILE OF SCHOOL LITERACY MOVEMENT AS AN EFFORT TO INCREASE READING MOTIVATION FOR PRIMARY SCHOOL STUDENTS IN KABUPATEN BONE
}

\author{
Irma $^{1}$, Sitti Aida Aziz ${ }^{2}$, Sulfasyah ${ }^{3}$ \\ ${ }^{1,2,3}$ Magister Pendidikan Dasar, Universitas Muhammadiyah Makassar, Makassar, Indonesia \\ 'irma23jpe@gmail.com,.'fkipida@gmail.com, sulfasyah@unismuh.ac.id
}
PROFIL GERAKAN LITERASI SEKOLAH SEBAGAI UPAYA MENINGKATKAN MOTIVASI MEMBACA SISWA SEKOLAH DASAR DI KABUPATEN BONE

\begin{tabular}{|c|c|}
\hline ARTICLE HISTORY & ABSTRACT \\
\hline $\begin{array}{l}\text { Submitted: } \\
18 \text { Oktober } 2020 \\
18^{\text {th }} \text { Oktober } 2020\end{array}$ & $\begin{array}{l}\text { Abstract: This study aimed to describe the implementation of school literacy movement program (SLM) to } \\
\text { increase students' reading motivation at elementary school in cluster } 1 \text { of Kecamatan Tanete Riattang Barat, } \\
\text { Kabupaten Bone. This study also aimed to reveal supporting and inhibiting factors in implementing SLM as } \\
\text { well as the strategies developed by schools to overcome the inhibiting factors. This qualitative descriptive } \\
\text { study utilized observations, interviews, and documentation to collect the data. The instruments of this study } \\
\text { were observation sheets and interview guidelines. The subjects of this study were } 15 \text { respondents consisting } \\
\text { of the principal, teachers, and students of grade VI and III. The results showed that the school implemented } \\
\text { SLM program through habituation, development, and classroom learning activities. This program included } \\
\text { the provision of facilities and infrastructure (such as libraries, reading corners, reading gardens, wall } \\
\text { magazines, posters and slogans). In addition, SLM program was implemented because of the support from } \\
\text { the school committee, school extra-curricular activities, and the provision of school funding allocations. } \\
\text { Meanwhile, the inhibiting factors were the students' lack of understanding about the implementation of SLM, } \\
\text { the inbalanced capacity of library capacity to the number of students, the insufficient book collection, and } \\
\text { the minimum time available for reading activities. Thus, strategies to overcome these factors were providing } \\
\text { students with an understanding of the application of SLM, expanding the reading garden, updating the book } \\
\text { collection in the library, and making the maximum use of time during must-read hours. } \\
\text { Keywords: literacy movement, reading motivation }\end{array}$ \\
\hline
\end{tabular}

Accepted:

20 Mei 2021

Abstrak: Penelitian ini bertujuan untuk mendeskripsikan bagaimana implementasi program gerakan literasi sekolah (GLS) dalam meningkatkan motivasi membaca siswa sekolah dasar gugus 1 kecamatam Tanete Riattang Barat kabupaten Bone, faktor pendukung dan penghambat GLS serta strategi yang dikembangkan sekolah untuk mengatasi faktor penghambatnya. Penelitian deskriptif kualitatif ini menggunakan metode observasi, wawancara dan dokumentasi dalam pengumpulan datanya yang dibantu dengan lembar observasi, pedoman wawancara. Subyek penelitian 15 responden yang terdiri dari kepala sekolah, guru kelas VI dan III serta siswa kelas VI dan III. Hasil penelitian menunjukkan bahwa sekolah menerapkan program GLS melalui kegiatan pembiasaan, pengembangan dan pembelajaran di kelas. Program ini meliputi penyediaan sarana dan prasarana (seperti perpustakaan, pojok baca, taman baca, majalah dinding, poster dan slogan ). Program GLS ini dapat terlaksana dengan adanya dukungan dari

Published:

27 Juni 2021

$27^{\text {th }}$ June 2021 komite sekolah, kegiatan ekstra kurikuler sekolah dan penyediaan alokasi dana dari sekolah. Sementara faktor penghambatnya adalah kurangnya pemahaman siswa terhadap penerapan GLS, kapasitas perpustakaan yang tidak seimbang dengan jumlah siswa, koleksi buku yang masih kurang, minimya waktu yang tersedia pada saat kegiatan membaca. Strategi untuk mengatasi faktor penghambat pada penerapan GLS adalah memberikan pemahaman kepada siswa tentang penerapan GLS, memperluas taman baca, memperbaharui koleksi buku di perpustakaan, serta memanfaatkan waktu secara maksimal saat jam wajib baca.

Kata Kunci: gerakan literasi, motivasi membaca

\section{CITATION}

Irma, I., Aziz, S. A., \& Sulafasyah. (2021). The Profile of School Literacy Movement as an Effort to Increase Reading Motivation for Primary School Students in Kabupaten Bone. Primary: Jurnal Pendidikan Guru Sekolah Dasar, 10 (3), 656-668. DOI: http://dx.doi.org/10.33578/jpfkip.v10i3.8200.

\section{PENDAHULUAN}

Salah satu hasil kajian literasi tingkat sekolah dasar yang dilakukan oleh lembaga
Progress in International Reading Literacy Study (PIRLS) dimana di tahun 2011 diperoleh data bahwa negara Indonesia berada pada 
urutan 42 dari 45 negara yang dilibatkan dalam survei ini. Lebih lanjut, di tahun 2015, kemampuan literasi siswa di Indonesia juga diklaim masih rendah dimana Indonesia berada pada urutan 61 dari 65 negara yang dievaluasi dengan skor rata-rata 397 (OECD, 2017). Pada tahun 2018, kembali dirilis hasil evaluasi yang dilakukan oleh PISA dimana diperoleh gambaran bahwa skor membaca Indonesia berada di peringkat 72 dari 77 negara dengan skor rata-rata 371 (OECD, 2018; OECD, 2019). Hal ini mengindikasikan bahwa skor PISA Indonesia mengalami penurunan skor dibandingkan dengan hasil tiga tahun lalu di tahun 2015.

Gambaran kemampuan membaca siswa tersebut didukung dari data yang diperoleh United Nations Educational, Scientific and Cultural Organization (UNESCO) di tahun 2011 dimana ditemukan fakta bahwa kemampuan membaca masyarakat Indonesia masih sangat rendah, yakni hanya 0,001. Artinya, hanya ada satu orang dari seribu orang masyarakat Indonesia yang membaca buku (Mumpuni \& Nurbaeti, 2019). Selain itu, studi oleh Lembaga Nirbala, yang bergerak pada bidang pendidikan PISA dengan hasil surveinya diperoleh bahwa Indonesia berada di posisi dari 64 dari 65 negara. Hal ini menjelaskan bahwa negara Indonesia menempati urutan kedua dari belakang (Sa'diyah, 2015).

Rendahnya minat baca memang memprihatinkan mengingat hal ini terjadi di lingkungan sekolah (Mulasih \& Hudhana, 2020). Pemaparan data-data sebelumnya menunjukkan bahwa tema literasi adalah persoalan kontekstual dunia pendidikan, oleh karenanya sangat penting untuk dikaji. Berbagai faktor yang mempengaruhi motivasi baca siswa diantaranya judul dan isi buku yang tidak menarik serta harga buku yang tidak terjangkau (Antari, Sundari \& Wulan, 2016). Padahal membaca memiliki manfaat praktis dalam kehidupan sehari-hari yaitu 1) terbukanya wawasan; 2) adanya pemikiran baru; 3) meningkatkan kecerdasan dalam segala bidang; dan 4) meningkatkan kemandirian dalam mencari pengetahuan, (Widodo, et al., 2020).

Berkaitan dengan rendahnya minat baca yang terjadi di atas ditanggapi secara serius oleh pemerintah melalui kampanye gerakan literasi. Budaya literasi dalam wujud membaca seharusnya sudah menjadi kebiasaan di lingkungan sekolah.

Gerakan Literasi Sekolah (GLS) adalah upaya meningkatkan gairah belajar siswa (Rusminati \& Rosidah, 2018). Kebijakan program GLS ini tercantum pada peraturan pemerintah pada Permendikbud RI Nomor 023 Tahun 2015 Tentang nilai-nilai budi pekerti. Program tersebut bertujuan untuk menumbuhkan lima budaya literasi di sekolah. Salah satu kegiatan dalam program ini adalah membaca buku non-pelajaran selama 15 menit sebelum pelajaran dimulai (Berliana \& Busyairi, 2019). Tujuan dari kegiatan ini adalah untuk meningkatkan motivasi membaca siswa serta dapat meningkatkan keterampilan membaca siswa.

Merujuk pada buku panduan GLS di sekolah dasar menurut Direktorat Jenderal Pendidikan Dasar dan Menengah Kementerian Pendidikan dan Kebudayaan, pelaksanaan program GLS terdiri atas tiga tahapan yaitu: (1) pembiasaan; (2) pengembangan; dan (3) tahap pembelajaran. Oleh karena itu, diperlukan metode atau cara yang baik sebagai upaya meningkatkan budaya literasi siswa agar menuai hasil yang maksimal tentunya melalui dukungan kepala sekolah, guru, dan orang tua siswa (Apriliyanto \& Sholeh, 2019; Rachmawati, Rohanda \& Winoto, 2017) . Salah satu cara yang dapat meningkatkan motivasi membaca siswa adalah memilih bahan bacaan yang di sukai anak namun tetap mendidik (Wahyuni, Djatmika \& As'ari, 2018). Selain itu, menggunakan buku cerita bergambar (komik) sebagai awal minat membaca (Setyawan \& Gusdian, 2020). Dengan demikian, dibutuhkan buku siswa yang memperhatikan aspek yang menjadi pertimbangan seperti ruang lingkup materi, 
HOTS, 4Cs, literasi baca-tulis (Fauziyah, 2020). Hal yang tak kalah penting adalah memotivasi minat baca siswa dengan didirikannya taman baca di sekolah (Rahayu \& Fakhruddin, 2019).

Beberapa faktor yang menghambat kegiatan literasi di sekolah selain kurangnya motivasi membaca siswa, adalah penyediaan sarana dan prasarana misalnya buku dan perpustakaan yang memadai. Lingkungan membaca yang kurang nyaman, buku bacaan yang tidak menarik, serta pengawasan dan dorongan dari orang tua serta masyarakat yang tidak maksimal (Aulawi, 2011; Riadi, 2019; Setyowati, 2019).

Hal ini pun terjadi di beberapa sekolah, khususnya yang ada di wilayah Kabupaten Bone yang belum mendapat bantuan perpustakaan. Data ini, menunjukkan bahwa jumlah perpustakaan yang kita miliki ternyata belum sebanding dengan jumlah sekolah yang ada. Padahal, dalam UndangUndang No. 43 Tahun 2007 tentang Perpustakaan pada bagian ketiga tentang Perpustakaan Sekolah/Madrasah, pada pasal 23 ayat 1 menyebutkan bahwa sekolah/madrasah menyelenggarakan perpustakaan yang memenuhi standar nasional perpustakaan dengan memperhatikan Standar Nasional Pendidikan. Undang-undang ini dengan tegas menyatakan bahwa setiap lembaga pendidikan wajib memiliki perpustakaan. Karena perpustakaan bukan hanya sebagai tempat penyimpangan buku bacaan tetapi fungsi lain perpustakaan sebagai sarana/ tempat membaca bagi siswa.

Sekolah Dasar di wilayah gugus I kecamatan Tanate Riattang Barat Kabupaten Bone merupakan sekolah kompleks yang terdiri dari tiga sekolah yaitu SD Negeri 22 Jeppe'e, SD Negeri 23 Jeppe'e, dan SD Inpres 12/79 Jeppe'e adalah contoh sekolah di Kabupaten Bone yang menerapkan program GLS. Gerakan tersebut adalah salah satu program budaya sekolah yang telah diputuskan oleh kepala sekolah bersama dewan guru, komite sekolah, orang tua siswa dan kalangan masyarakat, yang bertujuan untuk meningkatkan motivasi membaca siswa.

Oleh karena itu, motivasi membaca siswa perlu ditelusuri lebih mendalam melalui gerakan literasi sekolah dengan memperhatikan aspek pendukung dan penghambat dari program tersebut serta strategi apa yang harus ditempuh untuk meminimalisir penghambat gerakan literasi di sekolah.

\section{METODE PENELITIAN}

Dengan memilih jenis penelitian kualitatif dengan pendekatan deskriptif dimana penelitian ini mendeskripsikan implementasi gerakan literasi dalam upaya meningkatkan motivasi membaca siswa di sekolah, faktor pendukung dan penghambat terhadap penerapan GLS serta solusi yang dikembangkan untuk mengatasi masalah dalam penerapan GLS di Sekolah Dasar Gugus 1 Kecamatan Tanete Riattang Barat Kabupaten Bone. Adapun instrumen yang digunakan adalah lembar observasi, pedoman wawancara tak terstruktur dan kamera untuk mendokumentasikan proses pengumpulan data. Lembar observasi dan pedoman wawancara dikembangkan berdasarkan komponen gerakan literasi sekolah yaitu tahap pembiasaan, pengembangan dan pembelajaran. Selain itu, data pendukung yang diperoleh dari proses dokumentasi kegiatan implementasi Gerakan Literasi Sekolah (GLS) berlangsung dan aktivitas membaca siswa saat di sekolah. Adapun subjek penelitian yang dilibatkan adalah kepala sekolah, guru dan siswa kelas III dan IV sekolah dasar di wilayah gugus I kecamatan Tanate Riattang Barat Kabupaten Bone yaitu SD Negeri 22 Jeppe'e, SD Negeri 23 Jeppe'e, dan SD Inpres 12/79 Jeppe'e. Untuk memproleh data yang absah (valid) maka dilakukan uji kredibilitas data dengan menggunakan triangulasi metode yaitu membandingkan data hasil observasi dan wawancara. Data yang valid selanjutnya dianalisis dengan menggunakan model Miles 
dan Huberman yang meliputi reduksi data, penyajian data dan penarikan simpulan.

\section{HASIL DAN PEMBAHASAN}

Pemaparan hasil penelitian terkait dengan implementasi program Gerakan Literasi Sekolah Gugus 1 kecamatan Tanete Riattang Barat terhadap upaya meningkatkan motivasi membaca siswa sekolah dasar, faktor pendukung dan penghambat dalam penerapan GLS dan strategi untuk mengatasi faktor penghambat dalam penerapan GLS.

\section{Implementasi Program GLS sebagai Upaya Meningkatkan Motivasi Membaca}

Hasil penelitian ini menunjukkan bahwa implementasi program Gerakan Literasi Sekolah Gugus 1 Kecamatan Tanete Riattang Barat kabupaten Bone telah terlaksana sesuai dengan peraturan pemerintah Permendikbud No 23 tahun 2015 yang meliputi pada tiga tahapan yaitu tahap pembiasaan, pengembangan dan tahap pembelajaran. Berikut adalah pemaparan program implementasi GLS terhadap upaya meningkatkan motivasi membaca siswa sekolah dasar.

a. Tahap Pembiasaan

$$
\text { Hasil observasi penelitian }
$$
menunjukkan bahwa ketiga sekolah tersebut telah melaksanakan program wajib membaca 15 menit sebelum pelajaran dimulai. Hal ini didukung dari pernyataan guru kelas III, Ibu MR, dan guru kelas VI, Ibu MS, SD Negeri 22 Jeppe'e dimana program membaca dilaksanakan setiap hari sabtu di pagi hari, yaitu pukul 7.15 hingga pukul 7.30 WITA (MR,24/10/20; MS,31/10/20). Data ini juga didukung hasil wawancara dengan kepala sekolah di sekolah tersebut yang menyatakan bahwa kegiatan GLS pada tahap pembiasaan diprogramkan melalui kegiatan jam wajib baca setiap hari Sabtu dengan kegiatan membaca lima belas menit sebelum pelajaran dimulai (JR, 17/10/20).

Hal serupa yang diterapkan di SD Negeri 23 Jeppe'e dimana kegiatan GLS diadakan setiap hari Selasa pada pagi hari yang dilaksanakan selama 15 menit sebelum pelajaran dimulai. Hal ini didukung dari hasil wawancara dengan Ibu WL selaku guru kelas III dan bapak AR sebagai guru kelas VI dimana keduanya menyatakan bahwa kegiatan literasi yang diprogramkan sebagai budaya literasi dilaksanakan setiap hari Selasa yaitu 15 menit sebelum jam pertama pembelajaran dimulai di kelas (WL,03/10/20; AR,10/10/20).

Penjelasan dari kedua guru tersebut didukung oleh pernyataan ibu kepala sekolah, Ibu MN, yang mengemukakan bahwa kegiatan pembiasaan tetap dianjurkan untuk dilaksanakan dimana semua wali kelas agar selalu mengingatkan siswanya membaca 15 menit sebelum pelajaran dimulai (MN,26/9/20).

Hal serupa yang terjadi di SD Inpres 12/79 Jeppe'e dimana strategi pengembangan gerakan literasi sekolah dalam tahap pembiasaan adalah dengan menyediakan waktu jam wajib baca setiap hari selasa. Dimana pelaksanaannya didasarkan pada hasil keputusan dewan guru dengan mewajibkan siswa datang lebih cepat 15 menit dari jam masuk pada umumnya yaitu yang awalnya jam masuk 07.30 menjadi pukul 07.15 sehingga jam pelajaran tidak terganggu.

Deskripsi ini didukung dari hasil wawancara dengan guru kelas III, Ibu HS, dan guru kelas VI, Pak AM, dimana keduanya mengemukakan bahwa sekolah menjadwalkan jam wajib baca 15 menit sebelum pelajaran dimulai pada setiap hari Selasa (HS, 06/10/20; AM, 09/10/20). Pendapat ini dipertegas oleh kepala sekolah Ibu HJ yang menyebutkan bahwa kegiatan membaca merupakan kegiatan wajib yang harus dilakukan setiap siswa dengan cara memajukan jam masuk sekolah yaitu 07.15 Wita agar semua siswa mendapat kesempatan membaca secara bersamaan dengan durasi 15 menit (HJ, 29/09/20).

Berdasarkan paparan di atas dapat dijelaskan bahwa sekolah menjadwalkan jam wajib baca 15 menit sebelum pelajaran dimulai dimana kegiatan ini merupakan salah 
satu wujud pelaksanaan gerakan literasi sekolah yang merupakan tindak lanjut dari Permendikbud RI No 23 tahun 2015 tentang penumbuhan budi pekerti.

b. Tahap Pengembangan

Tindak lanjut kegiatan GLS setelah tahap pembiasaan adalah tahap pengembangan. Dari hasil pengolahan data diperoleh gambaran bahwa setiap sekolah di gugus I Kecamatan Tanete Riattang Barat melakukan kegiatan pada tahap pengembangan dengan berbagai teknik membaca diantaranya melakukan teknik kegiatan dengan pemilihan bahan bacaan fiksi dan non fiksi, membaca bersama dan melaksanakan kegiatan membaca dengan teknik membaca terpandu.

Hal ini diperkuat dengan hasil wawancara dengan Kepala Sekolah JR yang menyampaikan bahwa strategi kegiatan pengembangan diserahkan kepada guru kelas masing-masing untuk memantapkan kegiatan GLS dengan memilih buku pelajaran atau menggunakan buku fiksi dan non fiksi (JR, 17/10/20).

Hal senada yang dikemukakan oleh Ibu MS dan Ibu MR yang memperkuat perntaan ibu kepala sekolah bahwa salah satu kegiatan tahap pengembangan GLS adalah pemilihan bahan bacaan siswa dimana siswa dapat memilih bahan bacaan yang telah disediakan apakah itu jenisnya fiksi ataupun non fiksi (MS, 31/10/20; MR, 24/10/20).

Aktivitas membaca ini dilakukan dalam rangka peningkatan motivasi membaca melalui teknik membaca bersama di kelas dimana hal ini sesuai dengan pernyataan kepala sekolah MN yang menyatakan bahwa tujuan dari kegiatan ini adalah untuk memotivasi siswa dalam kegiatan membaca dimana pada kegiatan membaca bersama mengarahkan kemampuan siswa untuk melatih perkembangan bahasa anak (MN, 26/09/20).

Pernyataan tersebut didukung oleh bapak WL yang menyatakan bahwa kegiatan membaca bersama memberikan pengalaman kepada siswa tentang kefasihan membaca, (WL, 03/10/2020). Lebih lanjut, bapak AR mempertegas bahwa tujuan dari kegiatan membaca yaitu memberikan kesempatan kepada siswa untuk dapat lebih berkreatif dan menambah kepercayaan diri mereka serta melatih keterampilan berbicara siswa (AR, 10/10/20).

Pendapat di atas dipertegas oleh siswa kelas VI PR dan kelas III UL yang menyatakan bahwa kegiatan membaca yang dilakukan setiap hari Selasa sebelum pembelajaran dimulai dapat memotivasi membaca dan mempermahir cara membaca. Selain itu, memperlancar kami dalam menulis. (PR, 07/11/20; UL, 07/11/2020).

Hal ini disebabkan karena keterlibatan guru dalam mendampingi siswa ketika membaca di kelas dengan menggunakan atau menerapkan teknik membaca terpandu. Pernyataan ini dipertegas oleh bapak AM bahwa sebagai guru kelas enam hal yang dapat dilakukan adalah memandu siswa dalam kelompok kecil (4-5 anak) sehingga siswa dapat meningkatkan pemahaman mereka terhadap isi bacaan disajikan (AM, 13/10/20).

Senada dengan pendapat Ibu HS yang menyatakan bahwa kegiatan membaca membagi siswa kedalam kelompok kecil, memudahkan guru untuk memberi kesempatan kepada siswa untuk menjelaskan tujuan bacaan dan ringkasan isi bacaan sehingga siswa memahami isi bacaan yang disajikan (HS, 6/10/20).

Dari pemaparan sebelumnya dapa dijelaskan bahwa kegiatan Gerakan literasi Sekolah (GLS) pada tahap pengembangan adalah menerapkan program kegiatan yang dapat meningkatkan motivasi membaca siswa sekolah dasar melalui pemilihan bahan bacaan baik fiksi maupun non fiksi, membaca bersama dan teknik membaca terpandu.

c. Tahap Pembelajaran

Hasil observasi menunjukkan bahwa ketiga sekolah pada gugus I kecamatan Tanete Riattang Barat kabupaten Bone melaksanakan teknik kegiatan pembelajaran sebagai bagian dari penerapan kurikulum 2013. Ketiga sekolah tersebut, melakukan berbagai kegiatan 
dengan teknik meningkatkan motivasi membaca diantaranya melaksanakan teknik membaca nyaring dan teknik kegiatan membaca mandiri.

Kegiatan ini berlangsung di SD 22 Jeppe'e dimana ibu guru kelas VI MS menyatakan bahwa sejak adanya kurikulum 2013 pada saat kegiatan pembelajaran siswa diharapkan membaca materi dengan suara yang nyaring yang diharapkan dapat memperlancar bacaan siswa dan memahami pernyataan-pernyataan terkait apa yang siswa baca. (MS,31/10/20). Senada dengan yang diungkapkan oleh ibu kelas III, Ibu MR, yang menyatakan bahwa pada tahap pembelajaran ini, kegiatan yang dilakukan adalah menganjurkan siswa untuk membaca materi pelajaran dengan penerapan kurikulum 2013 yang berbasis saintifik dengan membaca nyaring dengan harapan siswa dapat memahami isi bacaan dengan memperhatikan kefasihan dan intonasi bacaan (MR,24/10/20).

Penerapan kurikulum 2013 melalui kegiatan membaca dengan teknik membaca mandiri terlaksana di SD 23 Jeppe'e dimana bapak AR sebagai wali kelas VI menyampaikan bahwa setiap hari sebagai kegiatan awal di kelas siswa dianjurkan untuk membaca buku teks selama lima menit secara mandiri dimana buku yang dibaca berkaitan dengan materi pembelajaran yang akan dipelajari (AR,10/10/2020).

Keterangan tersebut dipertegas oleh ibu guru kelas III, Ibu WL, yang menyampaikan bahwa sebelum pelajaran dimulai siswa dianjurkan untuk membaca mandiri yang bertujuan agar siswa dapat fokus dan konsentrasi dalam menerima materi pelajaran dengan membaca buku yang berkaitan materi pelajaran atau teks materi yang akan dipelajari pada hari tersebut (WL, 03/10/2020).

Pernyataan ini dipertegas oleh siswa PR yang menyatakan bahwa kegiatan GLS yang dilakukan selama ini selain dapat meningkatkan motivasi membaca juga dapat menambah wawasan dimana buku cerita yang dibagikan sangat bermanfaat yaitu dapat mengetahui pesan dan alur cerita pada bacaan (PR,7/11/2020). Senada dengan siswa UL yang menjelaskan bahwa dengan membaca buku, berbagai peristiwa atau informasi diperoleh. Selain itu perkembangan dan kemajuan ilmu pengetahuan dan teknologi dapat diketahui (UL, 7/11/20).

Pada SD Inpres 12/79 Jeppe'e kegiatan membaca dilakukan dengan menggunakan teknik membaca nyaring dalam rangka memotivasi kegiatan literasi membaca siswa. Hal ini, diungkapkan oleh ibu HS yang menyatakan bahwa kegiatan pada tahap pembelajaran dilakukan pada saat jam pelajaran berlangsung dimana dengan teknik membaca nyaring semua siswa diharapkan membaca materi bacaan pada buku pelajaran dengan memperhatikan tanda baca, lafal dan intonasi (HS,6/10/20).

Hal yang sama diungkapkan oleh pak AM bahwa teknik membaca nyaring dilakukan dengan cara memilih salah satu siswa yang dijadikan model atau contoh membaca di dalam kelas dengan harapan semua siswa fokus menyimak dan berkonstentrasi terhadap bacaan (AM, 13/10/20).

Dari pernyataan-pernyataan di atas memberikan penguatan bahwa sekolah pada gugus 1 Kecamatan Tanete Riattang Barat kabupaten bone telah melaksanakan program kegiatan literasi pada tahap pembelajaran dengan teknik membaca mandiri, dan teknik membaca nyaring. Penanaman budaya membaca di lingkungan sekolah telah diterapkan pada sekolah tersebut, jauh sebelum ditanamkan program Gerakan Literasi sekolah yang bertujuan untuk meningkatkan motivasi membaca siswa Sekolah Dasar.

\section{Faktor Pendukung Penerapan GLS sebagai Upaya Meningkatkan Motivasi Membaca Siswa}

Terkait dengan hasil penelitian yang menjadi faktor pendukung dalam penerapan program GLS yang didasarkan pada hasil observasi, wawancara dan dokumentasi yaitu 
penyediaan sarana dan prasarana dukungan dan pertisipasi dari pihak komite sekolah, serta penyediaan alokasi dana anggaran.

Sekolah Dasar gugus 1 kecamatan Tanete Riattang Barat kabupaten Bone dalam mewujudkan budaya literasi dengan memprogramkan pengadaan dan penyediaan sarana dan prasarana. Misalnya perpustakaan yang nyaman seperti yang diungkapkan oleh pak AR bahwa kenyamanan perpustakaan seperti penyediaan rak buku yang rapi, jaringan wifi dan koleksi buku yang menarik akan mempengaruhi minat baca siswa. Misalnya selain menyediakan buku paket juga disediakan buku dongeng atau buku cerita siswa sehingga membuat siswa lebih rajin mengunjungi perpustakaan (AR, 10/10/20).

Sekolah juga mengalokasikan anggaran pengelolaan perpustakaan. Anggaran ini selain untuk mengelola perpustakaan secara fisik, juga untuk keperluan pengadaan buku baru. Hal ini diungkapkan oleh pak AM bahwa suasana perpustakaan yang nyaman akan memberikan pengaruh positif terhadap motivasi siswa dalam membaca siswa dengan memberikan nuansa dan suasana baru dalam perpustakaan (AM, 13/10/20).

Pernyataan di atas diperkuat oleh ibu HS yang mengungkapkan bahwa dalam perpustakaan disediakan berbagai koleksi buku, mulai dari buku pelajaran sampai buku non pelajaran tujuan penyediaan buku ini agar siswa dapat lebih termotivasi untuk berkunjung di perpustakaan (HS, 06/10/20).

Selain itu, juga diadakan kunjungan wajib ke perpustakaan bagi siswa. Hal ini dituturkan oleh ibu HS bahwa terdapat jam wajib kunjungan ke perpustakaan dengan jadwal tertentu yang pelaksanaannya setelah pembelajaran di akhiri di kelas agar jam wajib belajar siswa di kelas tidak terganggu (HS, $6 / 10 / 20$ ).

Selain sarana perpustakaan, faktor pendukung kegiatan literasi pada ketiga sekolah tersebut adalah penyediaan pojok baca dan taman baca seperti yang diungkapkan oleh kepala sekolah 22 Jeppe'e Bapak JR bahwa dengan adanya pojok baca yang tersedia di kelas, siswa semakin rajin untuk melakukan kegiatan membaca (JR,17/10/2020). Hal ini dipertegas oleh Ibu MS yang menyatakan bahwa sejak adanya pojok baca siswa semakin gemar mengunjungi dan melakukan kegiatan membaca (MS, 31/10/20). Senada yang dikemukakan oleh ibu MR bahwa salah satu faktor yang mendukung kegiatan membaca adalah adanya penyediaan pojok baca dan taman baca, kedua tempat ini sangat diminati siswa pada saat jam wajib baca (MR,24/10/20).

Selain pojok membaca dan taman baca, majalah dinding dijadikan sebagai sarana pengembangan, atau penyaluran bakat siswa dalam kegiatan membaca. Hal ini diungkapkan oleh pak AM sebagai guru di SD Inpres 12/79 Jeppe'e bahwa dengan adanya mading yang di pasang di depan kelas siswa semakin gemar melakukan kegiatan menulis dan setiap hasil tulisan yang mereka pajang selalu saja menjadi bahan bacaan bagi siswa yang lain dengan demikian majalah dinding dapat mendorong motivasi membaca bagi siswa (AM,13/10/20).

Pernyataan ini didukung oleh ibu HS yang berpendapat bahwa majalah dinding dirancang dengan penuh variasi seperti memberikan kertas yang berwarna warni serta hiasan yang bergambar sehingga bacaan yang terdapat pada majalah dinding akan memberikan kesan untuk menarik minat siswa untuk membaca (HS, 6/10/20). Dengan demikian, majalah dinding di setiap kelas akan memberikan kesan yang dapat meningkatkan budaya literasi khususnya terhadap upaya meningkatkan motivasi membaca siswa.

Pelaksanaan implementasi penerapan GLS Sekolah dasar Gugus 1 Kecamatan Tanete Riattang Barat tak lepas partisipasi dari berbagai pihak terutama pada pihak komite sekolah. Hal ini dipertegas dari hasil wawancara dengan Ibu MS bahwa bantuan partisipasi dari pihak orang tua siswa dalam mendukung GLS di sekolah dilakukan demi kesuksesan siswa dan kusuksesan sekolah (MS, 31/10/20). Wujud partisipasi tersebut 
antara lain a) memberikan bantuan berupa penyediaan buku non pelajaran; b) memberikan dukungan kepada siswa dalam mengikuti kegiatan ekstrakurikuler misalnya lomba cipta dan baca puisi dan lomba story telling; c) memberikan dukungan dan partisipasi pada setiap ajang lomba yang diikuti di sekolah (lomba mendongeng, lomba membaca puisi bugis, lomba membaca lancar dsb.

Beberapa pernyataan di atas dipertegas oleh ibu HJ yang menyatakan bahwa pelaksanaan jam wajib baca merupakan dukungan dari orang tua siswa, hampir $80 \%$ siswa yang hadir tepat pukul 07.00, kegiatan ini terlaksana dengan baik berkat dukungan orang tua siswa (HJ,29/09/20). Pernyataan tersebut dipertegas oleh ibu HS yang menyatakan bahwa kesuksesan sekolah pada setiap ajang lomba ekstrakurikuler berkat dukungan dan partispasi orang tua (HS,6/10/20).

Beberapa pernyataan di atas memberikan penguatan bahwa komite sekolah sangat memberikan dukungan terhadap pelaksanaan GLS di sekolah. Wujud partisipasi komite baik secara moril maupun bantuan berupa sumbangan dana yang anggarannnya di peruntukkan untuk menyediaan taman baca siswa, sudut baca dan pojok literasi.

Selain pembiasaan budaya membaca lima belas menit sebelum pembelajaran di mulai, berbagai kegiatan ekstrakurikuler yang di bina di sekolah yang mendukung kegiatan GLS seperti pramuka, sanggar seni, drumband dan bidang olahraga. Hal ini diungkapkan oleh ibu MR bahwa berbagai kegiatan ekstrakurikuler yang bina di sekolah sangat memotivasi keterampilan membaca siswa seperti seni baca puisi, seni kaligrafi baca Alquran (MR, 24/10/20).

Hal ini dipertegas oleh ibu WL bahwa kegiatan ekstrakurikuler seperti membaca puisi bertujuan untuk mengembangkan bakat dan minat siswa; meningkatkan motivasi siswa pada kegiatan membaca dan meningkatkan kreatifitas anak (WL, 3/10/20). Hal ini juga dituturkan oleh ibu kepala sekolah MN berpendapat bahwa kegiatan ekstrakurikuler dapat meningkatkan motivasi membaca siswa.
Selain
pembinaan
kegiatan

ekstrakurikuler di sekolah dengan memberikan penghargaan kepada siswa yang aktif dalam kegiatan ekstrakurikuler Setiap siswa yang aktif pada kegiatan ekstrakurikuler akan mendapat sebuah piagam penghargaan ,dan apabila siswa tersebut meraih suatu kejuaraan maka siswa tersebut akan mendapat sebuah hadiah yang membuat siswa berbahagia. Hal ini dijelaskan Ibu kepala sekolah HJ bahwa untuk mendukung kegiatan ekstrakurikuler yang selama ini kurang diminati siswa maka dialokasikan dana untuk memberikan hadiah kepada siswa-siswi yang aktif pada kegiatan ekstrakurikuler (HJ, 29/09/20). Pernyataan tersebut dikuatkan oleh ibu kelas awal HS bahwa kepedulian kepala sekolah terhadap penerapan budaya literasi tampak pada pemberian hadiah kepada siswa yang aktif dalam kegiatan ekstrakurikuler sehingga penerapan GLS di sekolah dapat dilaksanakan secara berkelanjutan (HS, 6/10/20). Kebijakan kepala sekolah ini meningkatkan motivasi membaca siswa. Hal ini dipertegas oleh siswa AL bahwa setiap kegiatan jedah semester diadakan pertandingan antara siswa di kelas dimana siswa yang menang akan mendapat hadiah berupa buku tulis dan piagam (AL, 07/11/2020; NS, 07/11/20).

Dari penjelasan di atas dapat dijelaskan bahwa pemberian hadiah kepada siswa yang aktif pada kegiatan ekstrakurikuler merupakan bentuk kepedulian dalam menerapan gerakan Literasi sekolah (GLS). Hal ini juga merupakan bentuk apresiasi peningkatan prestasi dan motivasi belajar siswa baik secara akademik maupun non akademik.

Hal ini dapat terlaksana dengan dukungan penyediaan anggaran dari sekolah untuk kepentingan program GLS yang dilakukan melalui pengadaan buku baik buku fiksi maupun non fiksi, pengelolaan sarana dan prasarana termasuk fasilitas perpustakaan dan 
pendanaan kegiatan ekstrakurikuler (MN, 26/09/20).

Lebih jauh diutarakan oleh Pak AR bahwa pengadaan buku pelajaran sekolah dinggarkan dari dana sekolah sehingga semua siswa mendapatkan satu buku dari setiap tema pelajaran dan diperuntukkan untuk dipelajari dan bisa dibawa pulang ke rumah (AR, 10/10/20). Sekolah pun mengalokasikan dana untuk pengadaan dan pemeliharaan taman baca dan sudut baca di setiap kelas. Hal ini dinyatakan oleh ibu HJ bahwa biaya pengadaan dan pemeliharan perpustakaan, taman baca dan pojok literasi selalu diprogramkan di setiap triwulan (HJ, 29/09/20).

Hal senada yang diungkapkan oleh ibu HS dan Pak AM bahwa sekolah sangat peduli terhadap peningkatan mutu pendidikan dalam hal peningkatan motivasi membaca siswa dimana sekolah menganggarkan dana pengadaan modul belajar di rumah tujuannya agar semua siswa selama masa pendemi dapat tetap belajar di rumah (HS, 26/09/20; AM,13/10/20).

Beberapa pernyataan di atas merupakan bukti bahwa di sekolah pada gugus 1 kecamatan Tanete Riattang Barat mengalokasikan anggaran pada dana operasional sekolah sebagai bentuk pengadaan dan pemeliharaan sarana sekolah yang dapat mendukung penerapan Gerakan Literasi sekolah (GLS).

\section{Faktor Penghambat Penerapan GLS} sebagai Upaya Meningkatkan Motivasi Membaca Siswa

Untuk faktor penghambat pada penerapan GLS dapat dilihat dari beberapa pernyataan baik dari kepala sekolah maupun guru di ke tiga sekolah tersebut. Misalnya, Bapak Kepala Sekolah JR yang menyatakan bahwa pada saat jam wajib baca masih ada siswa yang tidak membaca mereka hanya berlari dan bermain ditaman baca yang berpengaruh pada penerapan GLS khususnya pada peningkatan motivasi membaca siswa (JR, 17/10/20). Pernyataan tersebut dipertegas oleh Ibu MS bahwa pada saat kegiatan membaca masih sering ditemukan siswa yang hanya bercengkama dan bercanda dengan teman-temannya (MS, 31/10/20).

Hal ini menggambarkan bahwa kurangnya pemahaman siswa terhadap penerapan GLS sehingga perlu ditanamkan kepada siswa bahwa budaya membaca sebagai bagian dari budaya literasi di sekolah yang perlu diterapkan pada diri setiap siswa. Namun, program GLS ini terkadang mengalami kendala karena kapasitas perpustakaan yang tidak seimbang dengan jumlah siswa. Hal ini diungkapkan oleh ibu HS dan Pak AR bahwa ruang perpustakaan terkadang tidak nyaman karena siswa duduk berdesak-desakan pada saat jam kunjungan perpustakaan (HS, 06/10/20; AR, 10/10/20).

Pernyataan di atas dipertegas oleh seorang siswa kelas VI AL yang mengungkapkan bahwa salah satu yang membuat malas ke perpustakaan adalah ruang perpustakaan yang kecil sehingga sering berdesak-desakan dan rebutan tempat duduk (AL, 07/11/20). Pernyataan didukung dari Ibu WL bahwa ketika jam wajib tiba siswa terkadang kurang termotivasi untuk mengunjungi perpustakaan dengan kondisi ruangan yang sempit dan tidak dapat menampung jumlah siswa (WL, 03/10/20). Pernyatan ini, merupakan salah satu gambaran penghambat pada penerapan Gerakan Literasi Sekolah di sekolah dasar.

Selain itu, warga sekolah belum memanfaatkan koleksi buku yang ada pada perpustakaan. MN sebagai kepala sekolah memberikan infromasi bahwa dari pihak sekolah menyediakan berbagai jenis buku baik buku pelajaran maupun buku bacaan, akan tetapi siswa masih terkadang kurang tertarik untuk membaca buku tersebut (MN, 26/09/20). Senada yang diungkapkan oleh pak AR bahwa salah satu yang menjadi penghambat dalam kegiatan GLS adalah pemanfaatan buku yang belum maksimal dimana perpustakaan telah menyediakan buku sangat banyak seperti buku pelajaran, buku fiksi dan buku non fiksi tetapi 
masih kurang menarik dan memotivasi siswa untuk membacanya (AR,10/10/20).

Pernyataan yang sama dikemukakan oleh Ibu HS dan pak AM bahwa pengadaan buku di sekolah sudah memadai hanya saja pemanfaatannya belum terlaksana secara maksimal, kami masih sering mendapatkan siswa yang kurang memanfaatkan buku (HS, 06/10/20; AM, 13/10/20). Beberapa pernyataan tersebut, memberikan gambaran bahwa pemanfaatan pepustakaan dan taman baca sebagai tempat membaca belum di laksanakan secara maksimal oleh warga sekolah. Masih ada warga sekolah yang belum menyadari bagaimana pemanfaatan sarana perpustakaan dan taman baca yang baik.

Tidak hanya itu, persoalan waktu yang disediakan di perpustakaan menjadi faktor penghambat. Minimnya waktu yang disediakan dipaparkan oleh siswa PR dan AQ menyatakan bahwa pada saat jam berkunjung di perpustakaan waktu yang disediakan untuk membaca sangatlah terbatas terkadang bacaan belum tuntas sehingga terkadang penasaran dengan isi bacaan tersebut (PR,07/11/20; AQ 07/11/20). Hal senada yang diungkapkan oleh bapak WL dan Ibu MS bahwa minimnya waktu yang tersedia membuat siswa tidak menyelesaikan bacaannya (WL, 03/10/20; MS, 31/10/20).

Beberapa pendapat di atas memberikan gambaran bahwa penyediaan waktu yang maksimal pada saat pelaksanaan jam wajib baca sehingga kegiatan gerakan literasi sekolah dapat memotivasi siswa untuk meluangkan waktu untuk membaca.

\section{Strategi untuk Mengatasi Faktor Penghambat/Kendala Penerapan GLS Dalam Meningkatkan Motivasi Membaca Siswa \\ Salah satu upaya yang dilakukan} Sekolah Gugus 1 Kecamatan Tanete Riattang Barat adalah memberikan pemaham siswa tentang pentingnya penerapan GLS khususnya terhadap upaya meningkatkan motivasi membaca. Hal ini merujuk pada penjelasan dari kepala sekolah bapak JR bahwa para pendidik memberikan pemahaman kepada siswa bahwa kegiatan membaca ini sangatlah bermanfaat selain melatihkan kemampuan membaca juga meningkatkan keterampilan menulis dan berbicara (JR,17/10/20).

Pendapat ini dipertegas oleh ibu MR menyatakan bahwa pemahaman tentang budaya literasi perlu dipahami oleh semua kalangan, seorang guru yang baik akan memberikan motivasi kepada siswanya sehingga guru harus menjadi contoh buat anak didiknya (MR, 24/10/20). Hal ini menunjukkan bahwa penerapan Gerakan Literasi Sekolah sangat membutuhkan dukungan dan partisipasi baik dari pihak kepala sekolah, tenaga pendidik, siswa, komite, orang tua siswa maupun pemerintah kabupaten.

Selain itu, sekolah berusaha menyediakan sarana baca yang menyenangkan, dengan upaya memperluas taman bacaan di halaman sekolah sehingga pada saat jam wajib membaca, siswa merasa nyaman dan tidak berdesakan di ruang perpustakaan. Penyataan ini diungkapkan oleh kepala sekolah MN bahwa untuk mengantisipasi jumlah siswa dengan kapasitas perpustakaan maka disediakan taman baca di area sekolah agar siswa tidak berdesak-desakan di perpustakaan (MN, 26/09/20). Ungkapan tersebut dipertegas oleh pak AR yang menyatakan bahwa dengan memperluas taman baca dapat mengantisipasi siswa yang berdesakan di perpustakaan (AR, 10/10/20).

Dengan memanfaatkan taman baca maka jam wajib membaca tetap dapat dilaksanan dengan baik. Hal ini dijelaskan oleh ibu HS dan pak AM bahwa untuk mengantisipasi jumlah siswa dengan lokasi perpustakaan maka siswa diminta untuk memanfaatkan taman baca, area baca untuk kegiatan jam wajib baca sehingga kegiatan ini tetap dapat memberikan kenyamanan kepada siswa pada saat membaca (HS, 06/10/20; AM13/10/20).

Berbagai pernyataan di atas memberikan penguatan bahwa salah satu solusi 
yang diterapkan untuk mengatasi kapasitas perpustakaan dengan jumlah siswa adalah memperluas dan memanfaatkan taman baca, area baca pada saat kegiatan jam wajib baca.

Tidak hanya itu, koleksi buku di perpustakaan pada ketiga sekolah tersebut perlu ditambah dan diperbaharui. Pihak sekolah juga berusaha menciptakan suasana penataan yang menarik di setiap sudut baca. Pernyataan ini disampaikan oleh bapak JR bahwa pihak sekolah selalu berusaha menambah koleksi-koleksi buku di perpustakaan agar siswa selalu mendapatkan hal yang baru dari bahan bacaan (JR,17/10/20). Pernyataan ini dipertegas oleh siswa kelas III RW yang mengemukakan bahwa salah satu yang dapat mengatasi rasa bosan kami pada bacaan adalah penyediaan koleksi buku baru sehingga kami rajin mengunjungi perpustakaan (RW,7/11/20).

Hal ini juga didukung dari pernyataan ibu MN bahwa sekolah berusaha menyediakan koleksi buku terbaru di setiap sudut baca, taman baca dan pojok literasi (MN,26/9/20) dan dipertegas oleh pak AR dan pak AM yang menjelaskan bahwa upaya yang sekolah lakukan terhadap pemanfaatan sarana perpustakaan adalah berupaya memperbaharui koleksi buku non pelajaran yang ada di pojok baca sehingga siswa selalu mendapatkan hal yang baru setiap bacaan yang mereka baca (AR, 26/9/20; AM, 13/10/20).

Pendapat ini senada apa yang diungkapkan oleh Ibu HS yang menyatakan bahwa sekolah selain berupaya menyediakan koleksi buku kami juga berupaya menyediakan fasilitas perpustakaan yang nyaman (HS, 06/10/20). Penjelasan ini menunjukkan bahwa strategi sekolah untuk mengatasi permasalahan tentang koleksi buku yang kurang diminati siswa adalah dengan menambah dan memperbaharui koleksi buku bacaan di perpustakaan, taman baca dan pojok baca di kelas.

Selain memperbaharui koleksi buku, juga memanfaatkan waktu secara maksimal yang disediakan oleh sekolah. Untuk mengantispasi hal tersebut pihak sekolah, guru dan orang tua siswa berusaha memprogramkan kegiatan literasi sekolah dengan tujuan utama meningkatkan motivasi membaca siswa dengan cara penyediaan jam wajib baca secara maksimal. Hal ini diungkapkan oleh ibu kepala sekolah Ibu MN dan bapak JR bahwa pihak sekolah berusaha mengoptimalkan jam wajib baca dengan memprogramkan jam wajib baca menjadi kan waktu lebih lama yang dulunya kami hanya programkan 15 menit sebelum pembelajaran kami dari pihak sekolah berupaya memajukan jam wajib baca khusus setiap hari selasa yaitu pukul 07.00 artinya kami mengupayan semua siswa mendapat kesempatan 15 menit sebelum lonceng sekolah berbunyi (MN, 26/09/20; JR, 17/10/20).

Hal yang sama diungkapkan oleh pak AR dan Ibu MR yang menyatakan bahwa sekolah berusaha mendisiplinkan siswa pada saat jam wajib membaca dengan memberikan sanksi yang bersifat mendidik bagi siswa yang terlambat (AR,10/10/20; MR, 24/10/20). Dengan demikian dari penjabaran tersebut dapat dijelaskan bahwa strategi yang dilakukan untuk mengatasi faktor penghambat terhadap penerapan Gerakan Literasi Sekolah Dasar gugus 1 kecamatan Tante Riattang Barat kabupaten Bone adalah memberikan pemahaman kepada warga sekolah tentang penerapan GLS, memperluas taman baca, memperbaharui koleksi buku di perpustakaan, serta memanfaatkan waktu secara maksimal pada saat jam wajib baca.

\section{SIMPULAN DAN REKOMENDASI}

Dari hasil penelitian yang dipaparkan diperoleh profil program penerapan Gerakan Literasi Sekolah (GLS) di sekolah dasar wilayah gugus 1 Kecamatan Tanete Riattang Barat Kabupaten Bone telah diterapkan berdasarkan Permendikbud No 23 Tahun 2015 tentang pengembangan budi pekerti yang mengarah pada tiga tahapan yaitu tahap pembiasaan, pengembangan dan pembelajaran. Adapun faktor yang mendukung pelaksanaan GLS ini yaitu pengadaan sarana dan prasarana, 
dukungan dan pertisipasi dari pihak komite sekolah serta penyediaan alokasi dana untuk pengadaan dan pemeliharaan sarana dan prasarana pendukung GLS. Sementara faktor penghambat dari penerapan GLS diantaranya adalah kurangnya pemaham siswa terhadap penerapan GLS, kurangnya pemanfaatan koleksi buku serta minimnya waktu yang tersedia pada saat jam wajib baca di sekolah. Dengan demikian dibutuhkan strategi tertentu agar GLS dapat terlaksana untuk meningkatkan motivasi membaca siswa di sekolah melalui pemberian pemahaman kepada siswa tentang penerapan Gerakan Literasi Sekolah (GLS), memperluas taman baca, menambah dan memperbaharui koleksi buku di perpustakaan, serta memanfaatkan waktu secara maksimal pada saat jam wajib baca. Oleh karena itu dibutuhkan kerjasama yang baik baik dari warga sekolah maupun masyarakat agar GLS ini dapat terlaksana dengan baik sehingga motivasi belajar dan membaca siswa tetap terjaga.

\section{DAFTAR PUSTAKA}

Antari, D. N., Sundari, N., \& Wulan, N. S. (2016). Studi Deskriptif Minat Baca Siswa Sekolah Dasar Kelas V Di Kota Serang. Antologi UPI, 4(2).

Apriliyanto, R., D., \& Sholeh, M. (2019). Strategi Kepala Sekolah Dalam Gerakan Literasi Untuk Peningkatan Keterampilan Berpikir Kritis Siswa Di SD Muhammadiyah 15 Surabaya. Inspirasi Manajemen Pendidikan, 7(1).

Aulawi, M. B. (2011). Optimalisasi layanan perpustakaan dalam meningkatkan minat baca siswa. Pustakaloka, 3(1), 117-127.

Berliana, A. O., \& Busyairi (2019). Implementasi Gerakan Literasi Sekolah Sebagai Penanaman Minat Baca Siswa Kelas IV. Joyful Learning Journal, 8(1), 25-30.

Fauziyah, U. S. (2020). Analisis Materi Pokok Bahasa Indonesia Pada Buku Tematik

$\begin{array}{lr}\text { Kelas III MI/SD } & \text { Revisi } \\ \text { 2018. EduHumaniora } & \text { Jurnal } \\ \text { Pendidikan Dasar } & \text { Kampus } \\ \text { Cibiru, 12(2), 91-100. } & \end{array}$

Miles, M. B., Huberman, A. M., \& Saldana, J. (2014). Qualitative data analysis: A methods sourcebook. Thousand Oaks, CA: Sage.

Mulasih, M., \& Hudhana, W. D. (2020). Urgensi Budaya Literasi Dan Upaya Menumbuhkan Minat Baca. Lingua Rima: Jurnal Pendidikan Bahasa dan Sastra Indonesia, 9(2), 19-23.

Mumpuni, A., \& Nurbaeti, R. U. (2019) Analisa Faktor yang Mempengaruhi Minat Baca Mahasiswa PGSD. DWIJA CENDEKIA: Jurnal Riset Pedagogik, 3(2), 123-132.

OECD. (2017). PISA 2015 Assesment and Analitycal Framework : Science, Reading, Mathematic, Financial Literacy and Collaborative Problem Solving. Retrieved 3 3, 2020, from oecd.org:

http://www.oecd.org/publications/pisa2015-assessment-and-analyticalframework-97 89264281820-en.htm

OECD. (2018). The future of education and skills, Education 2030. Retrieved 33 , 2020, from oecd.org: https://www.oecd.org/education/2030/ E2030\%20Position\%20Paper\%20(05. 04.2018). Pdf

OECD. (2019). PISA 2018 Result. Retrieved 1 5, 2020, from oecd: https://www.oecd.org/pisa/Combined Executive_Summaries_PISA_2018.pd $\mathrm{f}$

OECD. (2019). PISA 2018 Assessment and Analitycal Framework. Retrieved 2 27, 2020, from OECD: http://www.oecd.org/education/pisa2018-assessment-and-analyticalframework-b25e fab8-en.htm

Permendikbud. (2015). Permendikbud No 23 Tahun 2015 tentang Pengembangan Budi Pekerti: Panduan Penumbuhan 
Budi Pekerti. 2015. Jakarta: Sekretariat Ditjen Dikdasmen. Kemendikbud.

Rachmawati, T. S., Rohanda, R., \& Winoto, Y. (2017). Apresiasi Orangtua Siswa Terhadap Program Gerakan Literasi Sekolah (GLS). In Prosiding Seminar Nasional Pendidikan FKIP Untirta (Vol. 1, No. 2).

Rahayu, S., \& Fakhruddin, F. (2019). Manajemen Taman Bacaan Masyarakat (TBM) Sebagai Upaya Meningkatkan Budaya Literasi. Jurnal Eksistensi Pendidikan Luar Sekolah (E-Plus), 4(2).

Riadi, S. (2019). Metode Klos Meningkatkan Kecepatan Efektif Membaca (KEM). Media Nusantara-Jurnal Pendidikan, 1(1), 111-117.

Rusminati, S. H., \& Rosidah, C. T. (2018). Korelasi Penerapan Gerakan Literasi Sekolah (GLS) dengan Kemampuan Menyelesaikan Soal Cerita Matematika Siswa Di SDN Kebondalem Mojosari dan SDN Ketabang Surabaya. INVENTA: Jurnal Pendidikan Guru Sekolah Dasar, 2(2), 97-103.

Sa'diyah, Z. (2015). Peningkatkan minat baca siswa di SDI Bani Hasyim Singosari Malang (Doctoral dissertation, Universitas Islam Negeri Maulana Malik Ibrahim).

Setyawan, D., \& Gusdian, R. I. (2020). Penguatan Habitus Literasi: Sebuah Cara Pendampingan Tim Literasi Sekolah (TLS). E-DIMAS: Jurnal Pengabdian Kepada Masyarakat, 11(3), 299-306.

Setyowati, Y. N. (2019). Pengaruh Penggunaan Metode SQ3R dan Motivasi Belajar terhadap
Kemampuan Memahami Bacaan SIswa Kelas IV Madrasah Ibtidaiyah Se-Kecamatan Sawahan. Linguista: Jurnal Ilmiah Bahasa, Sastra, dan Pembelajarannya, 3(2), 80-90.

Wahyuni, P. D., Djatmika, E. T., \& As'ari, A. R. (2018). Pengaruh Full Day School dan Gerakan Literasi Sekolah terhadap Hasil Belajar dengan Mediasi Motivasi Belajar. Jurnal Pendidikan: Teori, Penelitian, dan Pengembangan, 3(5), 679-684.

Widodo, A., Indraswasti, D., Erfan, M., Maulyda, M. A., \& Rahmatih, A. N. (2020). Profil minat baca mahasiswa baru PGSD Universitas Mataram. Premiere Educandum: Jurnal Pendidikan Dasar Dan Pembelajaran, 10(1), 34-48. 